\title{
Phytotherapy - New Developments and Insights into Practice
}

\author{
Karin Kraft ${ }^{a}$ Jost Langhorst ${ }^{b}$ \\ ${ }^{a}$ Center of Internal Medicine, Universitätsmedizin Rostock, Rostock, Germany; \\ ${ }^{b}$ Department of Internal and Integrative Medicine, Kliniken Essen-Mitte, Faculty of Medicine, University of Duisburg-Essen, Essen, Germany
}

A public statement of the European Medicines Agency (EMA) from November 13th, 2014 states that 'Ten years since the introduction of the European legislation on herbal medicines, over 1,300 traditionally used herbal medicines have been registered, and more than 600 herbal medicines have been granted a marketing authorisation based on their well-established use in the EU Member States. These medicines are accompanied by clear and harmonised product information across the European Union, enabling citizens to make an informed choice when using herbal medicines for self-medication and healthcare professionals to base their prescription on comprehensive information on the medicines.' Indeed herbal medicines are used by millions of people in Europe, and 'the establishment of common standards for the licensing of herbal medicines across Europe has been essential to protect public health and allow citizens to trust the products they choose to use.' [1] The document also states that the initial focus of the EMA on European phytotherapy containing a single drug only will be extended in favor of medicines containing a combination of herbal ingredients as well as nonEuropean traditional medicines, such as Chinese medicines, used in Europe [1].

However, there is a pending problem in European phytotherapy which was addressed by Dr. Andreas Wenng, the representative of Swissmedic (Drug Regulatory Authorities of Switzerland), during the international congress on phytotherapy [2] ('Phytotherapie' 2014) in Winterthur, Switzerland, June 18 th -21 st. In his lecture, he introduced a provocative thesis: 'There is no future for herbal medicinal products!' Indeed, at present in Switzerland only up to 3 herbal medicinal products from new drugs successfully pass the marketing authorization procedure per year. Also the number of new herbal medicinal products from established medicinal drugs is limited. This problem, which is not mentioned in the state- ment of the EMA, is pending in the EU as well. The authorization problem results from the required evidence-based efficacy proof that causes costs in the range of EUR 30,000 up to EUR 1 Million for each product. However, in Switzerland and in the EU, the manufacturers of herbal medicinal drugs usually have limited financial resources. Dr. Wenng suggested that the lacking money could be raised by crowdfunding and pointed out that it is about time for European decision-makers to appreciate the benefit of European medicinal herbal products, such as low price, low cost in manufacturing, less drug-related side effects, and the still underachieved potential of natural resources of planet earth. This is even more urgent as many authorized herbal products are no longer available on the European market due to financial problems.

We believe that the present edition of FORSCHENDE KOMPLEMENTÄRMEDIZIN / RESEARCH IN COMPLEMENTARY MEDICINE can provide a valuable scientific support for the future strategy of the EMA, because it includes 3 excellent reviews which address European ethnoveterinary research [3], the presence of phytotherapy in German evidence-based medical guidelines [4], and the quality and safety of Chinese herbal drugs in Germany [5]. An essay on the concept of tonic [6] provides new insights into a traditional application of herbal medicine. In the section 'original articles' we are proud to present new research on a rather unknown herbal drug with a long-standing traditional use in Europe [7]. Additionally, there are also 2 clinical trials on Chinese herbal drugs [8, 9] which report herbal remedy use in rather severe indications.

This inspired the idea to look at the recent activity of our Chinese colleagues, who are lucky to be generously supported by their government for several years. This strategy seems to work: Since January 2013, 104 randomized controlled clinical trials with English abstracts on Chinese herbal preparations were published (source: PubMed). From the 54 trials available

\section{KARGER}

Fax +497614520714 (c) 2014 S. Karger AG, Freiburg

$1661-4119 / 14 / 0216-0345 \$ 39.50 / 0$
Karin Kraft, MD, PhD

Center of Internal Medicine

Universitätsmedizin Rostock

Ernst-Heydemann-Straße 6, 18057 Rostock, Germany

karin.kraft@med.uni-rostock.de 
in English, 23 are double-blind. A closer look at the indications examined in these trials revealed that the most of them are close to indications herbal medicinal drugs in Europe traditionally have been used for: chronic obstructive pulmonary disease (3 publications), asthma (2), ulcerative colitis (2), respiratory syndrome (1), functional constipation (1), functional dyspepsia (2), nephrolithiasis (1), dementia (2), insomnia (1), viral hepatitis (1), premenstrual and menopausal syndrome (4), endometriosis (3), infertility (1), pain (1), chronic heart failure (1), hypertension (2), diabetes mellitus type 2 (5), metabolic syndrome (1), rheumatoid arthritis (1), Sjögren's syndrome (1), cancer (4), and treatment of side effects of chemotherapy (1). Eleven further indications could be identified: Nephritis (Henoch-Schönlein) (1 publication), idiopathic membranous nephropathy (1), IgA nephropathy (1), primary glomular disease (1), ischemic stroke (3), severe pulmonary contusion (1), hand foot and mouth disease (1), acute pancreatitis (1), myasthenia gravis (1), polycystic ovary syndrome (1), and recurrent parotitis (1). The remaining 50 publications also deal with various common non-communicable diseases, but as they are published in Chinese, they were not further evaluated. However, all studies have common characteristics: The herbal preparations are mainly used as add-on medication to Western medicine, often based on main syndrome characteristics in traditional Chinese medicine, and they are often combined with other methods from Chinese medicine. Interestingly, in one study, Chinese phytotherapy was even combined with Western complementary medicine [10].

The recent publications from China indicate open-mindedness and show a very pragmatic way to address the needs of the patients, seemingly with both success and low cost. Hopefully this prosperous development in China will be noticed also by European decision makers and result in the urgently necessary increase of appraisal and support of modern European phytotherapy and other methods of European complementary medicine.

\section{References}

1 European Medicines Agency. http://www.ema.europa. eu/ema/index.jsp?curl $\% 20=\% 20$ pages/news_and events/news/2014/11/news_detail_002211.jsp\&mid\%20 $=\% 20$ WC0b01ac058004d5c1 (accessed 20.11.14).

2 Meier B: Willkommen zur Phytotherapie. Forsch Komplementmed 2014;21(suppl 1):1.

3 Mayer M, Vogl CR, Amorena M, et al.: Treatment of organic livestock with medicinal plants: a systematic review of European ethnoveterinary research. Forsch Komplementmed 2014;21:375-386.

4 Klose P, Kraft K, Cramer H, et al. Phytotherapie in den medizinischen S3-Leitlinien der Arbeitsgemeinschaft der Wissenschaftlichen Medizinischen Fachgesellschaften - eine systematische Übersichtsarbeit. Forsch Komplementmed 2014; 21:388-400.
5 Hempen N, Huber R: Qualität und Sicherheit chinesischer Arzneidrogen in Deutschland - ein Update. Forsch Komplementmed 2014;21:401-412.

6 Götti RP, Melzer J, Saller R: An approach to the concept of tonic: suggested definitions and historical aspects. Forsch Komplementmed 2014; 21:413-417.

7 Raak C, Molsberger F, Heinrich U, et al.: Mesembryanthemum crystallinum L. als dermatologisch wirksame Heilpflanze. Erste Ergebnisse aus drei Pilotstudien. Forsch Komplementmed 2014; 21:366-373.
8 Tianhong M, Yuxi Q, Zhimin W, et al.: Effect of Panax notoginseng in patients with multiple fractured ribs and pulmonary contusions caused by the 2008 Wenchuan earthquake. Forsch Komplementmed 2014;21:360-364.

9 Lin Y, Wang Y-F, Lin D-Q, et al.: Efficacy and safety of huxin formula in patients after CABG: a multicenter, double-blind, randomized, clinical trial. Forsch Komplementmed 2014;21:351-359.

10 Li JH, Zhou LX, Li GY, Cheng B: Treatment of middle-aged and aged patients with knee osteoarthritis of yang-deficiency induced cold-damp syndrome by ozone combined Chinese materia medica: a clinical research. Zhongguo Zhong Xi Yi Jie He Za Zhi 2013;33:471-475. 